Jurnal Health Sains: p-ISSN: 2723-4339 e-ISSN: 2548-1398

Vol. 2, No. 5, Mei 2021

\title{
HUBUNGAN PENGETAHUAN DENGAN PERILAKU SEDENTARI YANG BERISIKO OBESITAS PADA REMAJA DI KOTA MEDAN
}

Pika Asyera br Sinulingga, Lita Sri Andayani dan Zulhaida Lubis

Universitas Sumatera Utara (USU) Medan, Indonesia

Email: pika.asyera@gmail.com, lita_andayani@yahoo.com dan zulhaida.lubis@usu.ac.id

\begin{tabular}{l}
\hline ARTIKEL INFO \\
\hline Tanggal diterima: 5 Mei 2021 \\
Tanggal revisi: 15 Mei 2021 \\
Tanggal yang disetujui: 25 Mei \\
2021 \\
\hline
\end{tabular}

Keywords:

knowledge; attitude; sedentary

behavior; adolescents

\section{ABSTRACT}

Sedentary behavior is called sedentary physical activity or physical inactivity. At this time, teenagers are adopting a lot of temporary behavior, especially when the COVID-19 pandemic is currently happening, thus limiting the activities and activities of teenagers. Sedentary behavior can put you at risk of obesity. This study aims to see the relationship between adolescent knowledge and sedentary behavior. This type of research is a quantitative study using a cross sectional design. The number of respondents in this study consisted of 267 people. Data obtained through the results of questionnaires which were conducted online using google form. The results showed that 192 adolescents had good knowledge (71.9\%), 73 people (27.3\%) had sufficient knowledge, and $2(0.7 \%)$ had poor knowledge. that there is no relationship between knowledge and attitudes towards behavior while in adolescents. To see the relationship between knowledge and behavior, a statistical test was carried out using chi square, and the $p$ value was obtained $=$ $0.113(>\alpha=0.05)$. So it can be concluded that there is no relationship between knowledge and sedentary behavior at risk of obesity in adolescents in Medan.

\begin{abstract}
ABSTRAK
Perilaku sedentari disebut aktivitas fisik yang kurang bergerak atau ketidakaktifan fisik. Pada saat ini remaja banyak mengadopsi perilaku sedentari, terlebih lagi pada saat ini sedang terjadi pandemi COVID-19 sehingga membatasi aktivitas dan kegiatan remaja. Perilaku sedentari dapat menyebebakan risiko obesitas. Penelitian ini bertujuan untuk melihat hubungan pengetahuan remaja terhadap perilaku sedentari. Jenis penelitian merupakan penelitian kuantitatif menggunakan desain cross sectional. Jumlah responden penelitian ini terdiri dari 267 orang. Data diperoleh melalui hasil lembar kuisioner yang dilakukan secara online menggunakan google form. Hasil penelitian menunjukkan bahwa remaja memiliki pengetahuan yang baik berjumlah 192 orang $(71,9 \%)$, memiliki pengetahuan yang cukup berjumlah 73 orang $(27,3 \%)$, dan memiliki pengetahuan yang kurang baik berjumlah 2 orang $(0,7 \%)$, dan tidak terdapat hubungan pengetahuan dan sikap terhadap perilaku sedentari
\end{abstract}

\begin{tabular}{lllll}
\hline How to cite: & Asyera br Sinulingga Pika, et. al (2021) Hubungan Pengetahuan dengan Perilaku Sedentari yang \\
& Berisiko Obesitas pada Remaja di Kota Medan. Jurnal Health Sains 2(5). \\
& https://doi.org/10.46799/jhs.v2i5.156 & & & \\
E-ISSN: & $2723-6927$ \\
Published by: & Ridwan Institute
\end{tabular}


pada remaja. Untuk melihat hubungan pengetahuan terhadap perilaku sedentari dilakukan uji statistik menggunakan chi square, dan diperoleh nilai $p=0,113(>\alpha=0,05)$. Sehingga

Kata Kunci:

pengetahuan; sikap; perilaku sedentari; remaja dapat disimpulkan bahwa tidak ada hubungan pengetahuan dengan perilaku sedentari yang berisiko obesitas pada remaja di kota Medan.

\section{Pendahuluan}

Perilaku sedentari disebut aktivitas fisik yang kurang bergerak atau ketidakaktifan fisik. Kegiatan Sedentari (Sedentary) adalah kegiatan yang mengacu pada segala jenis aktivitas yang dilakukan di luar waktu tidur, dengan karakteristik keluaran kalori sangat sedikit yakni <1.5 METs. Perilaku Sedentari perlu dibatasi karena berbagai penelitian memperlihatkan bahwa perilaku ini menjadi risiko munculnya Obesitas (Kemenkes RI, 2019). Contoh perilaku sedentari berdasarkan (Kemenkes, 2018) yaitu berbaring atau duduk dalam waktu lama, seperti menonton tv, bermain video game, duduk lama di depan komputer; anak-anak pergi ke sekolah dengan diantar menggunakan kendaraan meskipun jaraknya dekat; perubahan kebiasaan misalnya orang pergi ke toko atau mini market hanya berjarak beberapa rumah dari tempat tinggalnya menggunakan mobil atau motor, pekerjaan rumah diserahkan kepada pembantu; kurang berolahraga; selalu menggunakan kendaraan bermotor untuk mencapai tempat yang jaraknya dekat; menggunakan lift meskipun akses tangga tersedia.

Perilaku sedentari menyebabkan banyak energi yang tersimpan sebagai lemak, sehingga orang-orang yang kurang melakukan aktivitas cenderung menjadi gemuk, dan dapat mengakibatkan penyakit PTM lainnya serta dapat menyebabkan kematian.

Data World Health Organization (Organization, 2018) menyatakan bahwa sekitar 2 juta kematian per tahun disebabkan oleh perilaku sedentari. Selain itu, 60 hingga $85 \%$ orang di dunia baik dari negara maju maupun negara berkembang menjalani gaya hidup perilaku sedentari dan empat dari lima remaja (11-17 tahun) tidak melakukan aktivitas fisik yang cukup. Data tersebut juga menyatakan bahwa $23 \%$ orang dewasa dan $81 \%$ remaja tidak memenuhi rekomendasi global WHO tentang aktivitas fisik untuk kesehatan. Sehingga gaya hidup yang mendominasi saat ini adalah gaya hidup perilaku sedentari.

Perilaku sedentari menjadi gaya hidup pada saat ini karena dipengaruhi oleh banyak hal, salah satunya kemajuan teknologi. Kemajuan teknologi bertujuan untuk memudahkan semua aktivitas menjadi lebih cepat, namun mengakibatkan manusia menjadi kurang bergerak. Seperti halnya saat ini, jika membeli televisi maka mendapatkan remote sebagai fasilitas untuk memudahkan penggunaan televisi tersebut, namum penggunaan remote menjadikan kurangnya aktivitas fisik. Hal tersebut dikuatkan oleh Pusat Data Republika (Islami, 2018) yang menyatakan bahwa remaja milenial menghabiskan waktunya 18 jam perhari untuk menikmati layanan tontonan on demand, bermain game, atau menonton televisi konvensional.

Selain penggunaan remote untuk membantu ketika menonton televisi, penggunaan smartphone juga mengakibatkan kurangnya aktivitas fisik oleh penggunanya karena tersedianya fitur-fitur aplikasi di dalam smartphone. Salah satu fitur aplikasi yang menyebabkan kurangnya aktivitas fisik adalah layanan ojek online yang menyediakan berbagai jasa untuk kemudahan penggunanya, seperti antar jemput dengan menggunakan kendaraan sepeda motor atau mobil, jasa 
mengirimkan barang, jasa untuk membeli makanan atau minuman, bahkan tersedia juga jasa untuk berbelanja ke supermarket yang diinginkan. Sehingga penggunanya hanya menggunakan smartphone dalam genggamannya untuk memenuhi semua kebutuhan yang diperlukan.

Penggunaan smartphone dan adanya kemajuan teknologi yang berkembang pesat mengubah gaya hidup di perkotaan yang menyebabkan berkurangnya remaja bermain dengan teman sebayanya di luar rumah (Praditasari \& Sumarmik, 2018). Hal ini juga dikuatkan oleh (Mandriyarini et al., 2017) yang menyatakan bahwa penurunan aktivitas fisik terjadi karena adanya perubahan gaya hidup seperti ke sekolah dengan menggunakan kendaraan atau diantar dengan mobil atau kendaraan umum. Selain itu, adanya perubahan desain perkotaan juga berdampak pada penurunan tingkat aktivitas fisik karena adanya peralihan dari jalan kaki dan bersepeda menjadi menggunakan kendaraan bermotor (Organization, 2018). Sehingga pada saat ini kurangnya aktivitas fisik juga dipengaruhi oleh adanya alat transportasi.

Selain adanya alat transportasi, fasilitas juga memengaruhi penurunan pada aktivitas fisik. Salah satu contoh yaitu adanya fasilitas eskalator dan lift yang disediakan oleh mall atau pusat perbelanjaan bagi pengunjungnya. Kemajuan teknologi memberi banyak sekali kemudahan akses dan fasilitas yang memengaruhi aktivitas fisik seperti sepeda motor, mobil, pesawat terbang, penggunaan eskalator dan peningkatan jumlah waktu yang dihabiskan untuk duduk di tempat kerja, sekolah, rumah, dan tempat umum (Lestari et al., 2018). Hal ini dikuatkan oleh (Organization, 2018) yang menyatakan bahwa ketika negara berkembang secara ekonomi, tingkat ketidakaktifan meningkat karena pengaruh perubahan pola transportasi, penggunaan teknologi, urbanisasi dan nilainilai budaya. Selain dari adanya kemajuan teknologi yang menyebabkan kemudahan akses dan fasilitas, peran orang tua juga penting dalam pemantauan kegiatan anak.

Terlebih lagi perubahan perilaku juga sedang terjadi saat ini, diakibatkan karena adanya kasus pandemi COVID-19. Perubahan perilaku tersebut mengakibatkan aktivitas lebih banyak dilakukan di dalam rumah, termasuk sekolah dari rumah (school from home). Hal tersebut merupakan program pemerintah yang dilakukan untuk memutus mata rantai penyebaran kasus COVID-19. Mendominasinya aktivitas yang dilakukan didalam rumah dapat berpotensi terjadinya perilaku sedentari karena terbatasnya aktivitas diluar rumah.

Survei pendahuluan dilakukan kepada 50 orang remaja di kota Medan, dan didapatkan hasil bahwa 44 orang (88\%) remaja cenderung berperilaku sedentari, dan terdapat 21 orang (42\%) remaja yang memiliki status gizi obesitas dan 13 orang (26\%) remaja memiliki status gizi lebih (overweight). Terlebih lagi pada saat ini terjadi pandemi COVID-19 yang mengakibatkan segala aktivitas dilakukan dari rumah, sehingga semakin dapat meningkatkan remaja untuk melakukan perilaku sedentari.

Beberapa penelitian mengungkapkan bahwa remaja yang memiliki asupan makronutrien berlebih, frekuensi konsumsi fast food yang sering, aktivitas fisik yang tidak aktif, memiliki ibu dan ayah dengan status obesitas, dan tidak sarapan, berisiko lebih besar mengalami obesitas (Kurdanti et al., 2015). Menurut Maulida mengatakan bahwa asupan energi, karbohidrat, lemak, protein, konsumsi fast food, dan riwayat obesitas orangtua berpengaruh terhadap kejadian obesitas pada remaja siswa sekolah menengah atas.

Berdasarkan uraian tersebut, peneliti tertarik untuk melakukan penelitian terhadap remaja mengenai perilaku sedentari yang berisiko obesitas. Tujuan dari penelitian ini adalah untuk mengetahui hubungan 
pengetahuan dengan perilaku sedentari yang berisiko obesitas pada remaja di kota Medan.

\section{Metode Penelitian}

Jenis penelitian dalam penelitian ini adalah penelitian kuantitatif dengan menggunakan desain cross sectional. Lokasi penelitian dilakukan di kota Medan, dengan mengambil $20 \%$ dari 21 kecamatan di kota Medan, sehingga didapatkan 4 lokasi penelitian. Penentuan lokasi kecamatan dipilih dengan menggunakan teknik cluster random sampling dengan menyusun daftar nama kecamatan berdasarkan dari kecamatan yang terluas, setelah itu dipilih secara acak. Sehingga diperoleh lokasi penelitian yaitu Medan Amplas, Medan Baru, Medan Timur, dan Medan Tuntungan.

Penelitian ini ditujukan kepada remaja berumur 15-19 tahun. Populasi remaja berumur 15-19 tahun di 4 kecamatan lokasi penelitian berjumlah 39.199 orang. Sehingga jumlah sampel yang didapatkan menggunakan tabel ISSAC dan MICHAEL adalah 267 orang dengan derajat kesalahan $10 \%$. Penentuan sampel pada penelitian ini menggunakan teknik purposive sampling dengan kriteria inklusi yaitu tinggal di lokasi penelitian; remaja berumur 15-19 tahun; memiliki smartphone; dan mampu mengaplikasikan google form.

Teknik pengumpulan data pada penelitian ini adalah dengan memberikan daftar pertanyaan dan jawaban secara online dengan menggunakan google form. Teknik analisis data pada penelitian ini adalah analisis univariat untuk memperoleh distribusi frekuensi dari sekolah secara online, dan analisis bivariat dengan menggunakan uji chi square untuk melihat pengaruh sekolah secara online terhadap perilaku sedentari yang berisiko obesitas dengan tingkat kepercayaan $95 \%$.

\section{Hasil dan Pembahasan}

Tabel 1

Distribusi Frekuensi Pengetahuan

\begin{tabular}{ccc}
\hline Pengetahuan & n & \% \\
\hline Baik & 192 & 71,9 \\
\hline Cukup & 73 & 27,3 \\
\hline Kurang & 2 & 0,7 \\
\hline
\end{tabular}

Hasil penelitian menunjukkan bahwa dari 267 orang terdapat sebanyak 192 orang $(71,9 \%)$ responden memiliki pengetahuan yang baik tentang perilaku sedentari, sebanyak 73 orang $(27,3 \%)$ responden memiliki pengetahuan yang cukup tentang perilaku sedentari, dan sebanyak 2 orang $(0,7 \%)$ responden memiliki pengetahuan yang kurang baik tentang perilaku sedentari. Dari penelitian ini didapatkan bahwa responden dominan memiliki pengetahuan yang baik tentang perilaku sedentari. Perilaku adalah segala tindakan ataupun segala aktivitas manusia yang dilakukan oleh manusia itu sendiri. Tentunya manusia dalam berperilaku dilakukan secara sadar dan dilakukan berdasarkan pengalaman yang berkaitan denga interaksi manusia dengan lingkungannya yang diwujudkan berdasarkan pengetahuan, sikap dan tindakannya sendiri (Skinner et al., 2015). Pengetahuan seseorang tentu memengaruhi perilaku seseorang. Harapannya pengetahuan yang baik tersebut akan mendorong seseorang untuk mau berperilaku.

\section{Tabel 2}

\begin{tabular}{|c|c|c|}
\hline \multicolumn{3}{|c|}{$\begin{array}{c}\text { Distribusi Frekuensi Perilaku Sedentari } \\
\text { yang Berisiko Obesitas }\end{array}$} \\
\hline $\begin{array}{c}\text { Perilaku sedentari yang } \\
\text { berisiko obesitas }\end{array}$ & n & $\%$ \\
\hline Berisiko obesitas & 110 & 41,2 \\
\hline Cukup berisiko obesitas & 137 & 51,3 \\
\hline Tidak berisiko obesitas & 20 & 7,5 \\
\hline
\end{tabular}

Berdasarkan tabel 2 menunjukkan data responden berperilaku sedentari yang berisiko obesitas yaitu sebanyak 110 orang $(41,2 \%)$ 
berisiko obesitas, sebanyak 137 orang $(51,3 \%)$ cukup berisiko obesitas dan sebanyak 20 orang $(7,5 \%)$ tidak berisiko obesitas.

Perilaku sedetari dapat menyebabkan terjadinya obesitas. Sehingga diperlukannya perilaku sehat seperti melakukan aktivitas fisik dan menjaga pola makan. Obesitas pada masa remaja dapat meningkatkan risiko penyakit kardiovaskuler ketika dewasa. sehingga perilaku sedentari harus diminimalisir dalam kehidupan sehari-hari untuk mencegah terjadinya obesitas.

Dari hasil penelitian ini dapat dilihat bahwa responden dominan kurang berisiko obesitas dalam perilaku sedentari yang berisiko obesitas. Kurang berisiko tidak menutup kemungkinan apabila tetap melakukan perilaku sedentari maka akan menjadi berisiko obesitas. Selain itu dengan jumlah responden sebesar $41,2 \%$ yang berisiko obesitas, seharusnya perhatian lebih harus dilakukan agar responden memiliki status gizi baik (normal).

Hal ini dikuatkan oleh penelitian (Zachary et al., 2020) yang menyatakan bahwa faktor risiko kenaikan berat badan selama karantina mandiri adalah kurang tidur, ngemil setelah makan malam, kurangnya pengekangan diet, makan sebagai respons terhadap stres, dan berkurangnya aktivitas fisik.

Tabel 3

Hubungan Pengetahuan dengan Perilaku Sedentari yang Berisiko Obesitas

\begin{tabular}{|c|c|c|c|c|c|c|c|c|}
\hline \multirow{3}{*}{ Pengetahuan } & \multicolumn{6}{|c|}{$\begin{array}{c}\text { Perilaku Sedentari yang Berisiko } \\
\text { Obesitas }\end{array}$} & TOTAL & \multirow{3}{*}{$\begin{array}{c}p- \\
\text { value }\end{array}$} \\
\hline & \multicolumn{2}{|c|}{ Berisikiko } & \multicolumn{2}{|c|}{ Cukup } & \multicolumn{2}{|c|}{ Tidak } & & \\
\hline & $\mathbf{N}$ & $\%$ & $\mathbf{n}$ & $\%$ & $\mathrm{n}$ & $\%$ & & \\
\hline Baik & 78 & 29,2 & 95 & 35,6 & 19 & 7 & 19271 , & \\
\hline Cukup & 32 & 12,0 & 40 & 15,0 & 1 & 0 , & 7327 , & 0,11 \\
\hline Kurang & 0 & 0 & 2 & 0,7 & 0 & 0 & 0,7 & \\
\hline
\end{tabular}

Untuk melihat hubungan antara pengetahuan dengan perilaku sedentari yang berisiko obesitas dilakukan dengan menggunakan uji Chi Square. Dari tabel 3 dapat diketahui bahwa remaja yang memiliki pengetahuan baik tetapi melakukan perilaku sedentari yang cukup berisiko obesitas yaitu sebanyak 95 orang $(35,6 \%)$. Remaja yang memiliki pengetahuan baik tetapi melakukan perilaku sedentari yang berisiko obesitas sebanyak 78 orang $(29,2 \%)$. Dari hasil data ini dapat dilihat bahwa pengetahuan yang baik belum tentu menjadikan perilakunya juga baik sesuai perilaku kesehatan. Hasil uji statistik dengan menggunakan uji Chi Square memperoleh nilai $\mathrm{p}$ sebesar 0,113 atau nilai $\mathrm{p}$ $>\alpha=0,05$ dengan derajat kepercayaan 95\%. Sehingga dapat disimpulkan bahwa tidak ada hubungan pengetahuan dengan perilaku sedentari yang berisiko obesitas pada remaja di kota Medan.

Hasil penelitian ini sejalan dengan penelitian (Astiningrum, 2017) yang menyatakan bahwa tidak ada hubungan pengetahuan tentang obesitas dengan kejadian obesitas siswa SMA Kesatrian 2 Semarang. Hasil yang sama sehingga memperkuat hasil penelitian ini juga terjadi pada penelitian (Tsurayya et al., 2018) yang menyatakan bahwa tidak terdapat hubungan yang bermakna antara pengetahuan gizi dengan obesitas pada remaja.

\section{Kesimpulan}

Berdasarkan hasil penelitian diperoleh bahwa tidak ada hubungan pengetahuan dengan perilaku sedentari yang berisiko obesitas pada remaja di kota Medan, dengan hasil uji statistik dengan menggunakan uji Chi Square memperoleh nilai p sebesar 0,113 atau nilai $\mathrm{p}>\alpha=0,05$ dengan derajat kepercayaan $95 \%$.

Sehingga dapat disimpulkan bahwa remaja memiliki pengetahuan yang baik mengenai perilaku sedentari yang berisiko obesitas. Namun pada tindakan yang dilakukan dalam aktivitas sehari-hari, remaja cukup berisiko dalam melakukan perilaku yang berisiko obesitas. Hal tersebut 
Pika Asyera br Sinulingga, Lita Sri Andayani dan Zulhaida Lubis

kemungkinan dapat terjadi karena dipengaruhi oleh faktor lain yang tidak ikut diteliti dalam penelitian ini.

\section{BIBLIOGRAFI}

Astiningrum, A. N. (2017). Hubungan Pengetahuan Tentang Obesitas, Keragaman Konsumsi Makanan Sumber Karbohidrat Dan Serat Dengan Kejadian Obesitas Siswa Sma Kesatrian 2 Kota Semarang. Universitas Muhammadiyah Semarang. Google Scholar

Islami, M. J. (2018). Tantangan Dalam Implementasi Strategi Keamanan Siber Nasional Indonesia Ditinjau Dari Penilaian Global Cybersecurity Index. Masyarakat Telematika Dan Informasi: Jurnal Penelitian Teknologi Informasi Dan Komunikasi, 8(2), 137-144. Google Scholar

Kemenkes, R. I. (2018). Contoh Perilaku Sedentari (1) Dan (2). Infographic P2ptm. Kemenkerian Kesehatan. Google Scholar

Kemenkes, R. I. (2018). Hasil Utama Riskesdas 2018. In Online) Http://Www. Depkes. Go. Id/Resources/Download/InfoTerkini/Materi_Rakorpop_2018/Hasil\% 20riskesdas (Vol. 202018). Google Scholar

Kemenkes Ri, K. R. I. (2019). Pedoman Gizi Seimbang. Stikes Perintis. Google Scholar

Kurdanti, W., Suryani, I., Syamsiatun, N. H., Siwi, L. P., Adityanti, M. M., Mustikaningsih, D., \& Sholihah, K. I. (2015). Faktor-Faktor Yang Mempengaruhi Kejadian Obesitas Pada Remaja. Jurnal Gizi Klinik Indonesia, 11(4), 179. Google Scholar

Lestari, T. W., Nurhayati, N., Delima, D., Opitasari, C., \& Siswoyo, H. (2018). Gambaran Tingkat Kepuasan Pasien
Pada Pelayanan Kesehatan Dengan Jamu Di Rumah Riset Jamu Hortus Medicus Tawangmangu. Jurnal Penelitian Dan Pengembangan Pelayanan Kesehatan, 81-86. Google Scholar

Mandriyarini, R., Sulchan, M., \& Nissa, C. (2017). Sedentary Lifestyle Sebagai Faktor Risiko Kejadian Obesitas Pada Remaja Sma Stunted Di Kota Semarang. Diponegoro University. Google Scholar

Maulida, Fabiaula Jillan. (2019). FaktorFaktor Yang Mempengaruhi Kejadian Obesitas Pada Siswa Sekolah Menengah Atas. Fakultas Ilmu Kesehatan. Universitas Muhammadiyah Surakarta. Google Scholar

Organization, W. H. (2018). Who Expert Consultation On Rabies: Third Report (Vol. 1012). World Health Organization. Google Scholar

Organization, W. H. (2018). Physical Activity. World Health Organization. Google Scholar

Organization, W. H. (2018). Who Launches Global Action Plan On Physical Activity. World Health Organization. Google Scholar

Praditasari, J. A., \& Sumarmik, S. (2018). Asupan Lemak, Aktivitas Fisik Dan Kegemukan Pada Remaja Putri Di Smp Bina Insani Surabaya [Fat Intake, Physical Activity And Obesity Among Adolescent Girls In Smp Bina Insani Surabaya]. Media Gizi Indonesia, 13(2), 117-122. Google Scholar

Skinner, C. S., Tiro, J., \& Champion, V. L. (2015). Background On The Health Belief Model. Health Behavior: Theory, Research, And Practice, 75, 1-34. Google Scholar

Tsurayya, A. H., Iman, A. Z., Sari, R. Y. A., Fauzi, A., \& Wijaya, G. S. (2018). Conceptual Shield Design For Boron Neutron Capture Therapy Facility Using 
Hubungan Pengetahuan dengan Perilaku Sedentari yang Berisiko Obesitas pada Remaja di Kota

Medan

Monte Carlo N-Particle Extended Simulator With Kartini Research Reactor As Neutron Source. Asean Journal On Science And Technology For Development, 35(3), 177-181. Google Scholar
Zachary, Z., Brianna, F., Brianna, L., Garrett, P., Jade, W., Alyssa, D., \& Mikayla, K. (2020). Self-Quarantine And Weight Gain Related Risk Factors During The Covid-19 Pandemic. Obesity Research \& Clinical Practice, 14(3), 210-216. Google Scholar

\section{Copyright holder:}

Pika Asyera br Sinulingga, Lita Sri Andayani dan Zulhaida Lubis (2021)

First publication right:

Jurnal Health Sains

This article is licensed under:

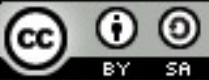

